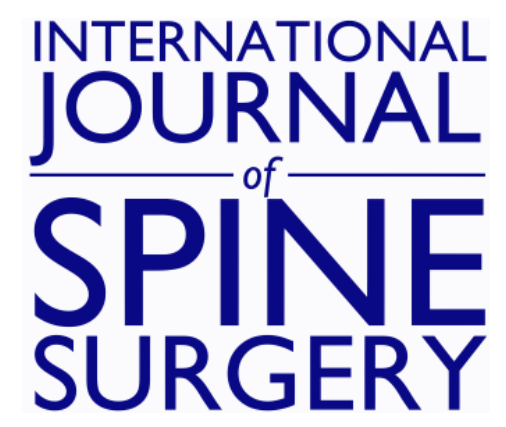

\title{
Mortality Prediction in a Vertebral Compression Fracture Population: the ASA Physical Status Score versus the Charlson Comorbidity Index
}

Elizabeth A. Demers Lavelle, Robert Cheney and William F. Lavelle

Int J Spine Surg 2015, 9 ()

doi: https://doi.org/10.14444/2063

http://ijssurgery.com/content/9/63

This information is current as of April 26, 2023.

Email Alerts Receive free email-alerts when new articles cite this article. Sign up at:

http://ijssurgery.com/alerts

The International Journal of Sphine Surgerbittp://ijssurgery.com/ by guest on April 26, 2 2397 Waterbury Circle, Suite 1,

Aurora, IL 60504, Phone: +1-630-375-1432

(C) 2015 ISASS. All Rights Reserved. 


\section{Mortality Prediction in a Vertebral Compression Fracture Population: the ASA Physical Status Score versus the Charlson Comorbidity Index}

Elizabeth A. Demers Lavelle, $M D,{ }^{1}$ Robert Cheney, $M D, 2$ William F. Lavelle, $M D^{1}$

${ }^{1}$ SUNY Upstate Medical University, Syracuse, NY, 2Albany Medical Center, Albany, NY

\section{Abstract}

Background

Morbidity and mortality scores are useful to control for medical comorbidities in study populations where either effects of an illness or benefits of a treatment are examined. Our study examined if a direct relationship existed between the American Society of Anesthesiologists Physical Status (ASA) score and the Charlson Comorbidity Index (CCI) in an osteoporosis population where patients had sustained a vertebral compression fracture.

\section{Methods}

A retrospective chart review of patients with osteoporotic compression fractures treated by the same orthopedic surgeon between June 2000 and June 2004 was performed. The primary endpoint was death by the close of the study period (September 2006). A board certified Anesthesiologist blindly assigned all of the ASA scores as well as the Charlson Scores independently in a blinded manner. All patients were assumed to be undergoing surgery as they were assigned. A statistical relationship was examined between ASA and CCI scores through a cross table analysis with chi-squared testing as both scoring systems were considered categorical. A Pearson correlation was completed to examine the quality of a linear relationship between the categorical variable ASA compared to the continuous variable Charlson. A value of $\mathrm{p}<0.05$ was considered significant.

Results

Ninety patients elected conservative therapy with oral analgesics and an orthosis, while 94 patients elected for kyphoplasty. The CCI by log rank testing was not significant $(p=0.2027)$ for the surgery population; however, the test resulted in a highly significant value $(\mathrm{p}=0.0161)$ in non-operative population. The ASA Score was correlated with significance to mortality $(\mathrm{p}=0.0150)$ for the surgery population, while the test was not significant $(\mathrm{p}=0.1439)$ in non-operative population. Treating both ASA and CCI scores as categorical variables, a relationship between them was examined and found to be highly significant $(\mathrm{p}=0.000001)$ meaning patients with low ASA scores were likely to have low CCI scores.

\section{Conclusion}

The ASA score was predictive of mortality in a surgical population, while CCI was highly predictive of mortality in a non-surgical population. There is great agreement between the CCI score and the ASA score, reflecting that anesthesiologists subjectively consider the same elements of the patient's medical history when assigning ASA scores as the CCI objectively uses. This was a Level III Study.

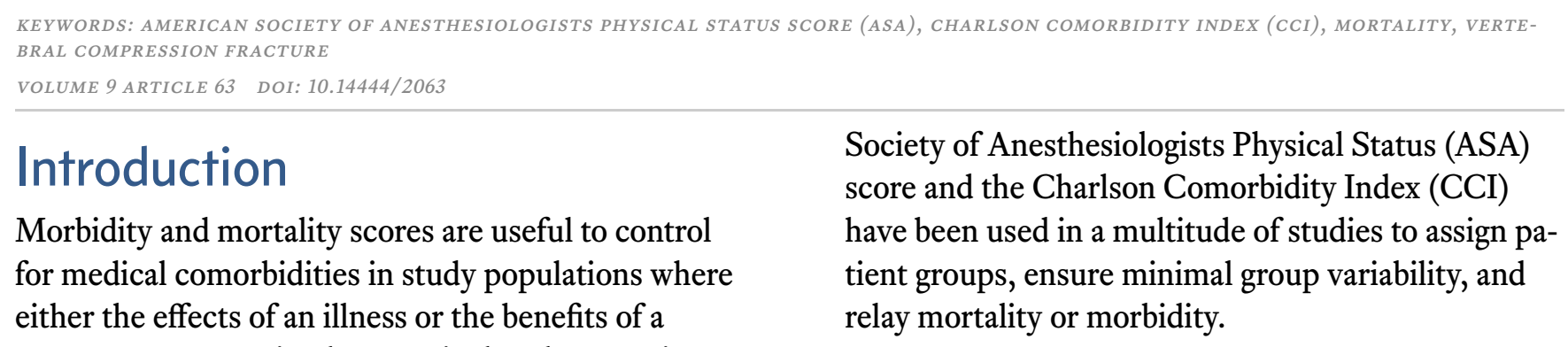

\section{Introduction}

Morbidity and mortality scores are useful to control for medical comorbidities in study populations where either the effects of an illness or the benefits of a

Society of Anesthesiologists Physical Status (ASA) score and the Charlson Comorbidity Index (CCI) have been used in a multitude of studies to assign patient groups, ensure minimal group variability, and relay mortality or morbidity. treatment are examined. In particular, the American

Downloaded from http://ijssurgery.com/ by guest on April 26, 2023 
In 1941, Rovenstein, Saklad, and Taylor published a grading system defining six degrees of physical state specifically "for the collection and tabulation of statistical data in anesthesia." Five categories of the American Society of Anesthesiologists Physical Status (ASA) Score was proposed by Dripps et al. in $1961{ }^{1}$ and accepted by the ASA in $1963 .{ }^{2}$ In October 2014, the American Society of Anesthesiologists adopted a six category classification system. ${ }^{3}$ The ASA score has become widely used to describe preoperative physical status (See Table 1). It is also used to predict peri-operative risk, ${ }^{4,5}$ despite the fact that it was never designed for this purpose. ${ }^{6}$ The Charlson Comorbidity Index was originally designed as a measure of the risk of one year mortality attributable to comorbidity in a longitudinal study of general hospitalized patients. Its contents and weighting scheme were created on the basis of Cox proportional hazards modeling. ${ }^{7}$ It was later adapted for International Classification of Diseases, Ninth Revision (ICD-9), codes to be used to calculate the Charlson Comorbidity Index with existing data. ${ }^{8} \mathrm{~A}$ weighted index of comorbidity is determined objectively based on the presence of nineteen medical conditions. This weighted index is then added to an age-related risk to determine an overall comorbidity score (See Table 2).

The purpose of this study was to examine if a direct relationship exists between the ASA score and the $\mathrm{CCI}$ in an osteoporosis population in which a patent has sustained a vertebral compression fracture. This study population was chosen because recent literature has found that osteoporosis, marked by vertebral compression fractures, may be a potential marker for increased mortality. Fractures of the hip and vertebral body are the most commonly associated injuries with increased post-injury mortality. ${ }^{9-15}$ Mortality after vertebral fractures has been reported to range between $16 \%$ and $60 \%$ greater than an unaffected population. ${ }^{15-17}$ In a previous publication, these two morbidity scores provided a control for the medical comorbidities of patients with osteoporosis who sustained vertebral compression fractures treated either surgically or conservatively. ${ }^{17} \mathrm{We}$ found both instruments to be statistically predictive of survival for the entire patient population. At that time, we did not examine the relationship between the two morbidity scales or whether either score was a better predictor of morbidity in the surgical versus non-operative patient population. Others have found a direct relationship between the CCI score and ASA score for survival in patients with genitourinary and head and neck cancer. ${ }^{18-19}$

\section{Methods}

A retrospective chart review of patients with osteoporotic compression fractures treated by the same orthopedic surgeon between June 2000 and June 2004 was performed. Patients received either nonoperative care consisting of oral analgesia and an orthosis, or surgical care with a kyphoplasty procedure. Patients with multiple myeloma, metastatic bone disease, or a burst fracture were excluded. Patients were diagnosed with a new vertebral compression fracture based on history and physical examination combined

\begin{tabular}{|c|c|c|}
\hline & $\begin{array}{l}\text { Preoperative } \\
\text { Health Sta- } \\
\text { tus }\end{array}$ & Comments \\
\hline ASA 1 & $\begin{array}{l}\text { Normal, } \\
\text { healthy pa- } \\
\text { tient }\end{array}$ & $\begin{array}{l}\text { No organic, physiologic, or psychiatric disturbance, } \\
\text { excludes the very young and very old, healthy with } \\
\text { good exercise tolerance }\end{array}$ \\
\hline ASA 2 & $\begin{array}{l}\text { Patients with } \\
\text { mild sys- } \\
\text { temic disease }\end{array}$ & $\begin{array}{l}\text { No functional limitations; has a well-controlled dis- } \\
\text { ease of one body system, controlled hypertension or } \\
\text { diabetes without systemic effects, cigarette smoking } \\
\text { without COPD, mild obesity, pregnancy }\end{array}$ \\
\hline ASA 3 & $\begin{array}{l}\text { Patients with } \\
\text { severe sys- } \\
\text { temic disease }\end{array}$ & $\begin{array}{l}\text { Some functional limitation; has a controlled disease } \\
\text { of more than one body system or one major system, } \\
\text { no immediate danger of death, controlled congestive } \\
\text { heart failure }(\mathrm{CHF}) \text {, stable angina, old heart attack, } \\
\text { poorly controlled hypertensions, morbid obesity, } \\
\text { chronic renal failure, bronchospastic disease with in- } \\
\text { termittent symptoms }\end{array}$ \\
\hline ASA 4 & $\begin{array}{l}\text { Patients with } \\
\text { severe sys- } \\
\text { temic disease } \\
\text { that is a con- } \\
\text { stant threat to } \\
\text { life }\end{array}$ & $\begin{array}{l}\text { Has at least one severe disease that is poorly con- } \\
\text { trolled or at end stage, possible risk of death, unsta- } \\
\text { ble angina, symptomatic COPD, symptomatic CHF, } \\
\text { hepatorenal failure }\end{array}$ \\
\hline ASA 5 & $\begin{array}{l}\text { Moribund } \\
\text { patients who } \\
\text { are not ex- } \\
\text { pected to sur- } \\
\text { vive without } \\
\text { surgery }\end{array}$ & $\begin{array}{l}\text { Not expected to survive }>24 \text { hours without surgery; } \\
\text { imminent risk of death; multiorgan failure, sepsis } \\
\text { syndrome with hemodynamic instability, hypother- } \\
\text { mia, poorly controlled coagulopathy }\end{array}$ \\
\hline ASA 6 & $\begin{array}{l}\text { A declared } \\
\text { brain-dead } \\
\text { patient } \\
\text { whose organs } \\
\text { are being re- } \\
\text { moved for } \\
\text { donor pur- } \\
\text { poses }\end{array}$ & \\
\hline
\end{tabular}


with plain radiographs and a bone scan and/or magnetic resonance imaging (MRI) when necessary to confirm the diagnosis and document fracture acuity.

The primary endpoint was death by the close of the study period which ended September 2006. Data were considered censored if the patient survived to the end of this study period. Patients were followed at an outpatient office. If recent follow-up was not obtained from the chart, patients were contacted by telephone to confirm their survival. Additionally, the Social Security Death index was reviewed for patient death during the study time period. Patient factors including age at the time of the initiation of conservative treatment, gender, and the presence of a previous non-acute compression fracture diagnosed by imaging at the time of the patient's assessment were also recorded. Medical comorbidity data were also collected from the patient's hospital and office charts. A CCI score was assigned to all patients by one physician following the guidelines established by Charlson et al. ${ }^{7}$ The online Charlson calculator provided by the Institute for Algorithmic Medicine was utilized to calculate the CCI. Charlson scores were grouped into 1, 2, 3, or 4+ to facilitate statistical evaluation. A single attending anesthesiologist assigned all patients an ASA score. A board certified Anesthe-

\begin{tabular}{|c|c|c|c|}
\hline $\begin{array}{l}\text { Weighted } \\
\text { Score }\end{array}$ & Condition & $\begin{array}{r}\text { Weighted } \\
\text { Score }\end{array}$ & Condition \\
\hline 1 & Myocardial infarct & 2 & Hemiplegia \\
\hline 1 & $\begin{array}{r}\text { Congestive heart } \\
\text { failure }\end{array}$ & 2 & $\begin{array}{r}\text { Moderate or severe renal } \\
\text { disease }\end{array}$ \\
\hline 1 & $\begin{array}{r}\text { Peripheral vascular } \\
\text { disease }\end{array}$ & 2 & $\begin{array}{r}\text { Diabetes with end organ } \\
\text { damage }\end{array}$ \\
\hline 1 & $\begin{array}{r}\text { Cerebrovascular } \\
\text { disease }\end{array}$ & 2 & Any tumor \\
\hline 1 & Dementia & 2 & Leukemia \\
\hline 1 & $\begin{array}{r}\text { Chronic pulmonary } \\
\text { disease }\end{array}$ & 2 & Lymphoma \\
\hline 1 & $\begin{array}{r}\text { Connective tissue } \\
\text { disease }\end{array}$ & 3 & $\begin{array}{r}\text { Liver disease, moderate } \\
\text { or severe }\end{array}$ \\
\hline 1 & Ulcer disease & 6 & Metastatic solid tumor \\
\hline 1 & Liver disease, mild & 6 & AIDS \\
\hline 1 & Diabetes & & \\
\hline
\end{tabular}

siologist blindly assigned all of the ASA scores as well as the Charlson Scores independently in a blinded manner. All patients were assumed to be undergoing surgery as they were assigned. This study only considered the medical comorbidity analysis as we have published on the effect of surgery (kyphoplasty) in a previous paper.

\section{Statistical Methods}

Data were recorded in an Excel Spreadsheet. NCSS/ PASS statistical analysis software (Kaysville, UT) was used to analyze the data. Patient survival curves were constructed for each of the study populations and subpopulations. Differences in survival based on comorbidity scoring were examined through log rank testing. A statistical relationship was examined between the ASA and CCI scores through use of a cross table analysis with chi-squared testing as both scoring systems were considered categorical. A Pearson Correlation was completed to examine the quality of a linear relationship between the categorical variable ASA compared to the continuous variable Charlson Score. A value of $\mathrm{p}<0.05$ was considered significant.

\section{Results}

Ninety patients elected for conservative therapy with oral analgesics and an orthosis, while 94 patients elected for kyphoplasty. All vertebral body fractures of fragility were included in the study. The survival plots for both surgical and non-surgical patients with their correlation to the ASA and CCI scores are seen in Figure 1 and Figure 2. The CCI by log rank testing was not significant $(p=0.2027)$ for the surgery population while the test resulted in a highly significant

\begin{tabular}{|c|c|c|c|}
\hline \multicolumn{2}{|c|}{ Operative Patients } & \multicolumn{2}{|r|}{ Non-Operative Patients } \\
\hline ASA Score & Charlson Score & ASA Score & Charlson Score \\
\hline All groups & All groups & All groups & All groups \\
\hline $\mathrm{p}=0.0150$ & $\mathrm{p}=0.2027$ & $\mathrm{p}=0.1439$ & $\mathrm{p}=0.0161$ \\
\hline ASA 2 vs. 4 & Charlson Score 1 vs. 4 & ASA 2 vs. 4 & Charlson Score 1 vs. 4 \\
\hline $\mathrm{p}=0.0073$ & $\mathrm{p}=0.0312$ & $\mathrm{p}=0.048$ & $\mathrm{p}=0.0063$ \\
\hline \multicolumn{4}{|c|}{$\begin{array}{l}\text { The } \mathrm{CCl} \text { correlation to mortality was not significant }(p=0.2027) \text { for the } \\
\text { surgery population but highly significant }(p=0.0161) \text { in the non-operative } \\
\text { population. The ASA Score correlation to mortality was significant }(p= \\
0.0150) \text { for the surgery population while the test was not significant } \\
(p=0.1439) \text { in the non-operative population. }\end{array}$} \\
\hline
\end{tabular}

Downloaded from http://ijssurgery.com/ by guest on April 26, 2023 
value $(\mathrm{p}=0.0161)$ in the non-operative population (See Table 3). The opposite was seen with the ASA score. The ASA Score was correlated with significance to the mortality $(p=0.0150)$ for the surgery population while the test was not significant $(p=0.1439)$ in the non-operative population.

Treating both the ASA and the Charlson scores as categorical variables, a relationship between the two was examined and found to be highly significant $(\mathrm{p}=$ 0.000001) meaning that patients with a low ASA scores were likely to have low CCI scores.

A linear regression model was created using Charlson Score as a dependent and continuous variable. An $R$ squared value of 0.330 was found with a signifi-

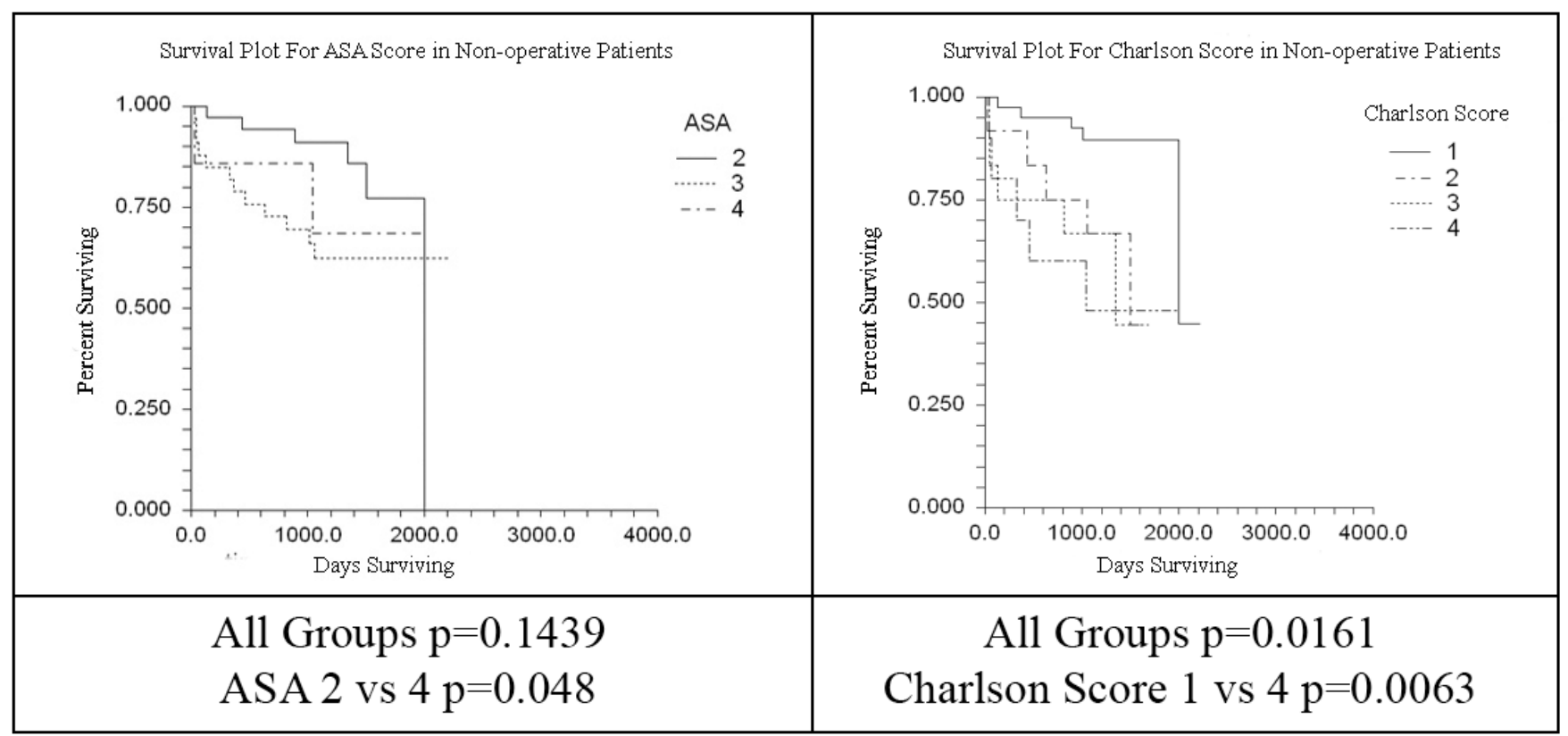

Fig. 1. Survival Plots for Nonoperative Patients.

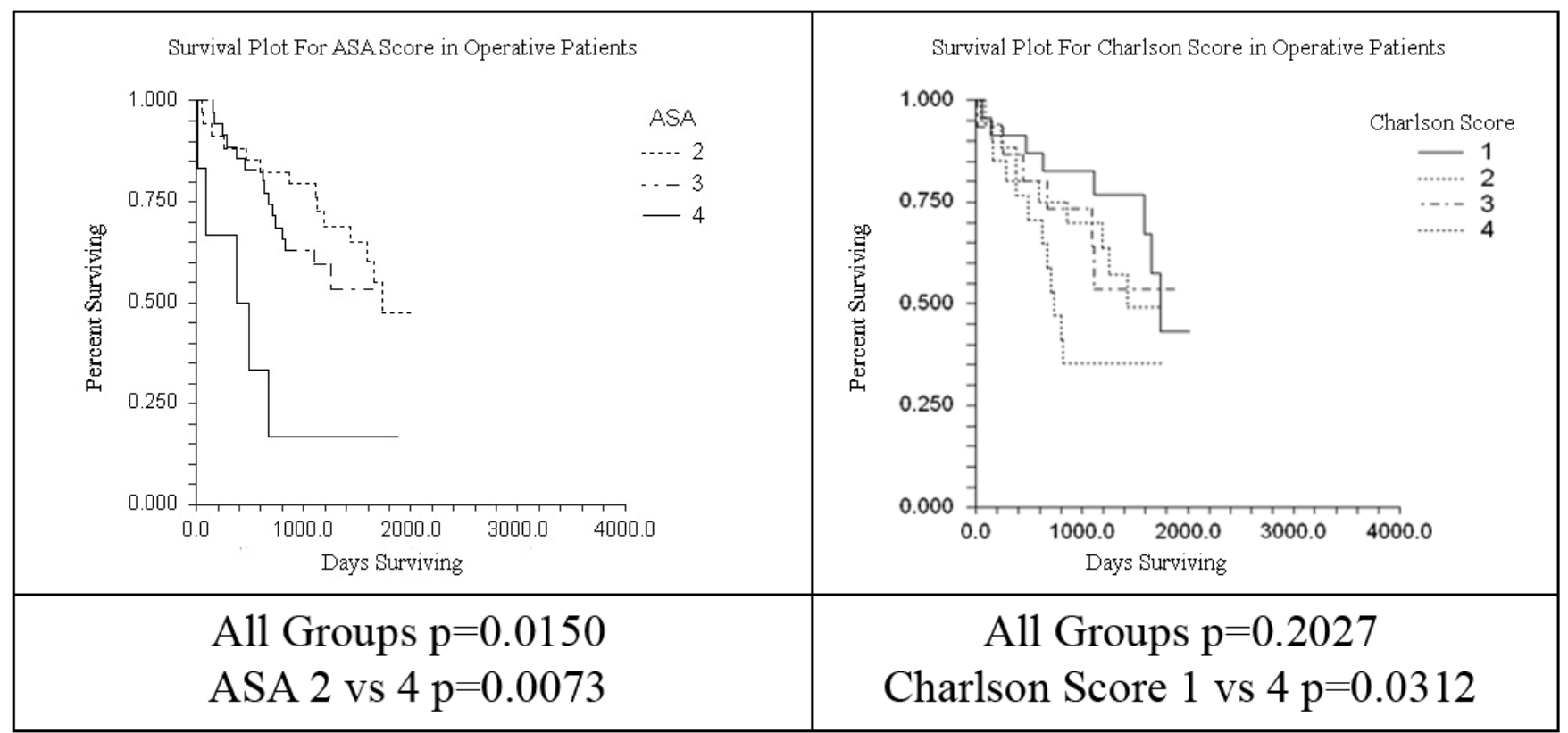

Fig. 2. Survival Plots for Operative Patients. 
cance value of $(\mathrm{p}=0.001)$. Table 4 , Table 5 , and Table 6 demonstrate the percentage of patients with each of the morbidity assessments. Table 7 demonstrates the mean morbidity scores for the operative and nonoperative populations.

\section{Discussion}

The American Society of Anesthesiologists (ASA) classification is a readily available and widely accepted method for stratification of surgical patients according to their peri-operative risk. ${ }^{19}$ ASA scores have been seen in multiple studies to have low interobserver reliability, but are frequently incorporated in studies to cite reduced variability and predict mortality. ASA scores are typically assigned at the bed- side immediately before surgery. These scores have been found to be predictive of mortality for a variety of other conditions. ${ }^{7,19}$ The ASA is a subjective assessment without a rigid formula used to assign a

\begin{tabular}{|l|r|r|r|r|}
\hline Table 7. Comparison of Mean Morbidity Scores. \\
\hline ASA & Mean & Std. Deviation & \\
\hline & Nonoperative & 2.631579 & 0.649966 & \\
\hline & Total & 2.630872 & 0.640407 & $\mathrm{P}=0.989$ \\
\hline Charlson Score & Nonoperative & 1.763158 & 1.615495 & \\
\hline & Operative & 2.465753 & 1.772335 & \\
\hline & Total & 2.107383 & 1.724783 & $\mathrm{P}=0.012$ \\
\hline
\end{tabular}

Table 4. Total Population Morbidity Scores.

\begin{tabular}{|c|c|c|c|c|c|c|c|c|c|c|}
\hline \multicolumn{11}{|c|}{ Charlson Score } \\
\hline & 0 & 1 & 2 & 3 & 4 & 5 & 6 & 7 & 8 & Total \\
\hline ASA 2 & $16.11 \%$ & $14.09 \%$ & $10.74 \%$ & $4.03 \%$ & $0.00 \%$ & $0.00 \%$ & $0.00 \%$ & $0.67 \%$ & $0.00 \%$ & $45.64 \%$ \\
\hline ASA 3 & $2.01 \%$ & $10.07 \%$ & $10.07 \%$ & $10.74 \%$ & $6.71 \%$ & $2.01 \%$ & $2.01 \%$ & $1.34 \%$ & $0.67 \%$ & $45.64 \%$ \\
\hline ASA 4 & $0.00 \%$ & $0.00 \%$ & $0.67 \%$ & $3.36 \%$ & $3.36 \%$ & $0.67 \%$ & $0.67 \%$ & $0.00 \%$ & $0.00 \%$ & $8.72 \%$ \\
\hline Total & $18.12 \%$ & $24.16 \%$ & $21.48 \%$ & $18.12 \%$ & $10.07 \%$ & $2.68 \%$ & $2.68 \%$ & $2.01 \%$ & $0.67 \%$ & $100.00 \%$ \\
\hline
\end{tabular}

Table 5. Non-Operative Morbidity Scores.

\begin{tabular}{|c|c|c|c|c|c|c|c|c|c|c|}
\hline \multicolumn{11}{|c|}{ Charlson Score } \\
\hline & 0 & 1 & 2 & 3 & 4 & 5 & 6 & 7 & 8 & Total \\
\hline ASA 2 & $20.27 \%$ & $16.21 \%$ & $6.76 \%$ & $2.70 \%$ & $0.00 \%$ & $0.00 \%$ & $0.00 \%$ & $0.00 \% \%$ & $0.00 \%$ & $45.94 \%$ \\
\hline ASA 3 & $1.35 \%$ & $16.21 \%$ & $8.11 \%$ & $10.81 \%$ & $4.05 \%$ & $1.35 \%$ & $1.35 \%$ & $1.35 \%$ & $0.00 \%$ & $44.59 \%$ \\
\hline ASA 4 & $0.00 \%$ & $0.00 \%$ & $1.35 \%$ & $2.70 \%$ & $2.70 \%$ & $1.35 \%$ & $1.35 \%$ & $0.00 \%$ & $0.00 \%$ & $9.45 \%$ \\
\hline Total & $21.62 \%$ & $32.43 \%$ & $16.22 \%$ & $16.22 \%$ & $6.76 \%$ & $2.70 \%$ & $2.70 \%$ & $1.35 \%$ & $0.00 \%$ & $100.00 \%$ \\
\hline
\end{tabular}

Table 6. Operative Morbidity Scores.

\begin{tabular}{|c|c|c|c|c|c|c|c|c|c|c|}
\hline \multicolumn{11}{|c|}{ Charlson Score } \\
\hline & 0 & 1 & 2 & 3 & 4 & 5 & 6 & 7 & 8 & Total \\
\hline ASA 2 & $12.00 \%$ & $12.00 \%$ & $14.67 \%$ & $5.33 \%$ & $0.00 \%$ & $0.00 \%$ & $0.00 \%$ & $1.33 \%$ & $0.00 \%$ & $45.33 \%$ \\
\hline ASA 3 & $2.67 \%$ & $4.00 \%$ & $12.00 \%$ & $10.67 \%$ & $9.33 \%$ & $2.67 \%$ & $2.67 \%$ & $1.33 \%$ & $1.33 \%$ & $46.67 \%$ \\
\hline ASA 4 & $0.00 \%$ & $0.00 \%$ & $0.00 \%$ & $4.00 \%$ & $4.00 \%$ & $0.00 \%$ & $0.00 \%$ & $0.00 \%$ & $0.00 \%$ & $8.00 \%$ \\
\hline Total & $14.67 \%$ & $16.00 \%$ & $26.67 \%$ & $20.00 \%$ & $13.33 \%$ & $2.67 \%$ & $2.67 \%$ & $2.67 \%$ & $1.33 \%$ & $100.00 \%$ \\
\hline
\end{tabular}

Downloaded from http://ijssurgery.com/ by guest on April 26, 2023 
score; therefore, it is inclusive of all available medical history and easily assigned.

In contrast, the Charlson Comorbidity Index instrument rigidly assigns a score based on the presence of specific comorbidities which possess various weights. To this end, Charlson scores are much less subjective, yet all conditions are not addressed by a Charlson score. CCI scores are a useful way to examine medical records as they may be calculated using recorded ICD-9 codes.

The goal of our analysis was to determine the agreement between these two comorbidity classification systems and to determine if one system predicted morbidity more reliably in surgical versus nonoperative subpopulations. Our data may suggest that the ASA is a better instrument for stratifying operative patients while the CCI score is better for nonoperative patients. However, this may be an effect of the population size of each group. It is more likely that this study merely illustrates that patients with poor scores in both systems are at a higher mortality risk while those identified at low risk in either system survived longer. Both systems have somewhat more difficulty stratifying patients of intermediate risks. This is where both systems are lacking. In comparisons made for other disease processes, such as cancer, authors have chosen to combine comorbidity classification subgroups when listing morbidity percentiles. Therefore, patients were regarded as either having a high or low degree of morbidity. It is not surprising that in both of our patient populations, when the lowest scoring and highest scoring patients were compared, both systems were highly significant for both surgical and non-operative patients. The relationship between these variables was examined categorically through a Chi Squared test which would imply that the Charlson scores for ASA groups differed statistically between each group. This relationship was also examined through a linear regression model. As the ASA score is not a continuous variable this would not be an ideal model to examine a potential relationship. Specifically, if treating the Charlson score as a continuous variable there are few patients with a score of greater than a four. This is why our assessment was completed in a categorical manner. Table 4 demonstrates that the percentage of patients with a categorically low ASA also had a categorically low Charlson Score.

Certainly a limitation of this study is that a single physician assigned either the ASA or Charlson score in a retrospective manner. Although an assignment of the Charlson score has little bias, multiple studies have determined that the ASA score has low interobserver reliability. The design through the use of a single anesthesiologist purposefully eliminated this variability for patient ASA assignments. However, the anesthesiologist who assigned these scores may simply assign scores which correlate more readily with mortality. A study with a larger group of anesthesiologists assigning both ASA and Charlson scores would eliminate this inherent bias. Additionally, all patients were assumed to be undergoing surgery when they were assigned ASA and Charlson scores. Since the anesthesiologist was not made aware of what treatment was given, this should not affect or cause bias to the scoring. On the other hand the surgeon would potentially select healthier patients on which to perform surgery. This may have had an effect on the differences seen in the survival curves for each of the study populations; however, our analysis revealed slightly worse Charlson Scores for the patients who had received surgery.

This study has definitively illustrated that there is a great deal of agreement between the Charlson Comorbidity Index score and the ASA score. This reflects that anesthesiologists subjectively consider the same elements of the patient's medical history when assigning ASA scores as the Charlson system objectively uses. This data may prove valuable for future studies as either of these pieces of data may be available in database reviews such as those of large insurance databases. As these resources become more available, tools such as comorbidity stratifying systems will be necessary for data analysis. They will potentially allow physicians and epidemiologists to make improved data comparisons. As our ability to mitigate tremendous public health concerns such as cancer and heart disease improves, we find an ever increasing osteoporotic population. Perhaps, our next frontier of healthcare will be identifying these more chronic and often thought benign diseases such as osteoporosis and attempting to improve upon pa-

Downloaded from http://ijssurgery.com/ by guest on April 26, 2023 
tient quality of life and potential geriatric patient survival.

\section{References}

1. Dripps RD, Lamont A, Eckenhoff JE. The role of anesthesia in surgical mortality. $J A M A .1961$ Oct 21; 178: 261-266.

2. American Society of Anesthesiologists. New classification of physical status. Anesthesiology. 1963; 24: 111.

3. American Society of Anesthesiologists. ASA Physical Status Classification System.

http://asahq.org/resources/clinical-information/asaphysical-status-classification-system Published October 15, 2014. Accessed April 21, 2015.

4. Derrington MC, Smith G. A review of studies of anaesthetic risk, morbidity and mortality. $\mathrm{Br} J$ Anaesth. 1987 Jul; 59(7): 815-833.

5. Cullen DJ, Apolone G, Greenfield S, Guadagnoli E, Cleary P. ASA Physical Status and age predict morbidity after three surgical procedures. Ann Surg. 1994 Jul; 220(1): 3-9.

6. Owens WD, Felts JA, Spitznagel EL Jr. ASA physical status classifications: a study of consistency of ratings. Anesthesiology. 1978 Oct; 49(4): 239-243.

7. Charlson ME, Pompei P, Ales KL, MacKenzie CR. A new method of classifying prognostic comorbidity in longitudinal studies: development and validation. J Chronic Dis. 1987;40(5):373-83.

8. Deyo RA, Cherkin DC, Ciol MA. Adapting a clinical comorbidity index for use with ICD-9-CM administrative databases. J Clin Epidemiol. 1992 Jun;45(6):613-9.

9. Bergeron E, Lavoie A, Moore L, Bamvita JM, Ratte $S$, Gravel C, et al. Is the delay to surgery for isolated hip fracture predictive of outcome in efficient systems? J Trauma. 2006 Apr;60(4):753-7. 10. Bottle A, Aylin P. Mortality associated with delay in operation after hip fracture: observational study. BMJ. 2006 Apr 22;332(7547):947-51. 11. Moran CG, Wenn RT, Sikand M, Taylor AM. Early mortality after hip fracture: is delay before surgery important? J Bone Joint Surg Am. 2005 Mar;87(3):483-9.

12. McGuire KJ, Bernstein J, Polsky D, Silber JH. The 2004 Marshall Urist award: delays until surgery after hip fracture increases mortality. Clin Orthop Relat Res. 2004 Nov;(428):294-301.

13. Zuckerman JD, Skovron ML, Koval KJ, Aharonoff G, Frankel VH. Postoperative complications and mortality associated with operative delay in older patients who have a fracture of the hip. $J$ Bone Joint Surg Am. 1995 Oct;77(10):1551-6.

14. Kado DM, Browner WS, Palermo L, Nevitt MC, Genant HK, Cummings SR. Vertebral fractures and mortality in older women. Arch Intern Med. 1999 Jun; 159(11): 1215-1220.

15. Cooper C, Atkinson EJ, Jacobsen SJ, O'Fallon WM, Melton LJ 3rd. Population-based study of survival after osteoporotic fractures. Am J Epidemiol. 1993 May 1; 137(9): 1001-5.

16. Ismail AA, O'Neill TW, Cooper C, Finn JD, Bhalla AK, Cannata JB, et al. 1998 Mortality associated with vertebral deformity in men and women: Results from the European Prospective Osteoporosis Study (EPOS). Osteoporos Int. 1998; 8(3):291-7.

17. Lavelle WF, Khaleel MA, Cheney R, Demers E, Carl AL.Effect of kyphoplasty on survival after vertebral compression fractures. Spine J. 2008 Sep-Oct; 8(5):763-9.

18. 18.Froehner M, Koch R, Litz R, Heller A, Oehlschlaeger S, Wirth MP. Comparison of the American Society of Anesthesiologists Physical Status classification with the Charlson score as predictors of survival after radical prostatectomy. Urology. 2003 Oct;62(4):698-701.

19. Reid BC, Alberg AJ, Klassen AC, Koch WM, Samet JM. The American Society of Anesthesiologists' class as a comorbidity index in a cohort of head and neck cancer surgical patients. Head Neck. 2001 Nov;23(11):985-94.

\section{Disclosures}

The authors declare no relevant financial disclosures.

\section{Corresponding Author}

William Lavelle, MD, 6620 Fly Road, Suite 200, East Syracuse, NY 13057. lavellew@upstate.edu

Published 12 November 2015.

This manuscript is generously published free of charge by ISASS, the International Society for the 
Advancement of Spine Surgery. Copyright @ 2015

ISASS. To see more or order reprints or permissions, see http://ijssurgery.com. 